\title{
O MOVIMENTO DE MULHERES CAMPONESAS NA CONSTRUÇÃO DO FEMINISMO CAMPONÊS POPULAR: PROTAGONISMO FEMININO, PRÁTICAS FEMINISTAS E HISTÓRIA DE LUTA
}

\author{
The Rural Women Movement in the construction of Rural Popular Feminism: \\ female protagonism, feminist practices and history of struggle
}

Débora Fragata dos Santos'

Silvia Aparecida Zimmermann²

\begin{abstract}
Resumo
A luta feminista foi fundamental na conquista de direitos básicos para as mulheres, sendo esta evidenciada principalmente pela ação das mulheres em contexto urbanizado, que tendo poucas vezes mencionadas as especificidades das mulheres rurais. Estas mulheres historicamente têm seus trabalhos produtivos invisibilizados e direitos negados, desde direitos profissionais, previdenciários, à terra, entre outros. Os movimentos de mulheres rurais no Brasil surgem da necessidade de uma organização que priorizasse suas demandas. 0 artigo tem como objetivo explicar a construção do Feminismo Camponês Popular (FCP) resultado da luta das mulheres rurais, apresentado através do histórico de ação de um dos mais importantes movimentos sociais autônomos de mulheres rurais brasileiros, o Movimento de Mulheres Camponesas (MMC). A metodologia utilizou uma pesquisa documental, bibliográfica e duas entrevistas semi estruturadas com lideranças do MMC, localizadas em regiões equidistantes no país, exemplos de luta que têm sua trajetória de vida imbricada no vínculo estabelecido com o Movimento. Os dados evidenciam a construção de um feminismo rural popular, não divergente do feminismo urbano, mais específico ao modo de vida rural.
\end{abstract}

Palavras Chaves: Feminismo Camponês Popular, Movimento de Mulheres Camponesas, Campesinato.

\begin{abstract}
The feminist struggle was fundamental for the conquest of basic women rights, marked by the action of women in an urbanized context, in which rural women's specificities are rarely mentioned. Historically, rural women have had their work invisibilized and their rights denied, from their professional and welfare matters, to land rights, among other issues. The rural women's movements in Brazil come from the necessity of an organization that could make their demands a priority. The article aims to explain the establishment of the Rural Popular Feminism (FCP, Feminismo Popular Camponês in Portuguese), a result of the rural women's struggle to be represented through the history of actions of one of the most

\footnotetext{
${ }^{1}$ Graduada em Desenvolvimento Rural e Segurança Alimentar em 2018 pela Universidade Federal da Integração Latino Americana UNILA. E-mail: debora.santos@aluno.unila.edu.br e/ou dehfragata2014@gmail.com Cidade: Foz do Iguaçu, PR, Brasil.

2 Professora Adjunta da Universidade Federal da Integração Latino-Americana (UNILA). Doutora de Sociologia em Desenvolvimento, Agricultura e Sociedade pela Universidade Federal Rural do Rio de Janeiro (2011). E-mail: silvia.zimmermann@unila.edu.br Cidade: Foz do Iguaçu, PR, Brasil.
} 
O movimento de mulheres camponesas na construção do feminismo camponês popular | Débora $F$. dos Santos \& Silvia Aparecida Zimmermann

important autonomous social movements of rural women in Brazil, the Rural Women Movement (MMC, Movimento das Mulheres (amponesas in Portuguese). The methodology used a documental and bibliographic research, as well as semi-structured interviews with two MMC's leaders, located in two equidistant regions of Brazil, two people that are examples of struggle that have imbricated their own life trajectories with the Movement. The data highlights the establishment of a rural popular feminism, that doesn't diverge from the urban feminism, although it is more specific to the rural way of life.

Keywords: Rural Popular Feminism, Rural Women Movement, Rural Women.

\section{Introdução}

Historicamente as mulheres sempre estiveram presentes, no espaço rural e urbano, na luta pelos direitos básicos e por melhores condições de trabalho de homens e mulheres. E foi a partir dessas experiências vivenciadas nas lutas que as mulheres rurais se organizaram com demandas especificas por direitos e liberdade para expressar sua voz e de suas companheiras. Diferentemente das mulheres urbanas, essas mulheres não tinham um modelo a seguir de feminismo, como encontramos na teoria feminista que surge nas grandes cidades. Foi a partir da vivência prática e de suas experiências pessoais, através da auto-organização e do intercâmbio de saberes herdados de geração a geração, que as mulheres forjaram um feminismo camponês popular.

Este artigo tem o intuito de explicar a construção do feminismo camponês popular (FCP) resultado da luta das mulheres rurais, apresentado através do histórico de ação de um dos mais importantes movimentos sociais autônomos de mulheres rurais no Brasil, o Movimento de Mulheres Camponesas (MMC). Essa construção é observada a partir dos relatos de duas mulheres rurais, exemplos de luta, que têm sua trajetória de vida imbricada no vínculo estabelecido com o Movimento. ${ }^{3}$

A metodologia para este trabalho, além de revisão bibliográfica e documental, implica na realização de duas entrevistas semiestruturadas com dirigentes nacionais do MMC localizadas na região sul e nordeste do país. As entrevistas ocorreram entre maio de junho de 2018, sendo uma das entrevistas presencial e a outra via Skype. Cabe ressaltar que outras lideranças e representações foram contatadas, inclusive de outros

\footnotetext{
3 Este artigo foi retirado do Trabalho de Conclusão de Curso intitulado "O Feminismo e os Movimentos Autônomos de Mulheres Rurais: o Movimento de Mulheres Camponesas e suas práticas feministas", defendido pela autora principal em julho de 2018, para a obtenção do título de Bacharel em Desenvolvimento Rural e Segurança Alimentar, na Universidade Federal da Integração Latino Americana (UNILA), Brasil.
} 
O movimento de mulheres camponesas na construção do feminismo camponês popular | Débora $F$. dos Santos \& Silvia Aparecida Zimmermann

movimentos sociais autônomos de mulheres rurais, mas infelizmente não tivemos retorno. Na sequência, as entrevistas foram transcritas e analisadas, e seu conteúdo foi fundamental para a compreensão da história, conquistas, mobilizações, articulações e lutas dos movimentos autônomos de mulheres rurais, em especial do MMC; e como esta luta se mescla com a história de vida e de luta de ambas as entrevistadas.

Foi em $1^{\circ}$ de maio de 1983 que teve início, com uma reunião que juntou 28 representantes de diferentes instituições, a consolidação de um movimento exclusivo de mulheres rurais, em Itaberaba, distrito de Chapecó na região Oeste de Santa Catarina, denominada Organização de Mulheres Agricultoras $(\mathrm{OMA})^{4}$, que contava com fundamental auxílio da Igreja Luterana, grupos de oração e grupo das mães das Comunidades Eclesiais de Base (CEBs) da Igreja Católica. Estas organizações foram as responsáveis, na época, pelo espaço de socialização da realidade doméstica das mulheres rurais, e consequentemente, levaram as mesmas ao questionamento das relações desiguais de gênero, encorajando-as na empreitada de criação de um movimento exclusivo às necessidades das mulheres trabalhadoras rurais.

Conforme Gaspareto (2017, p. 107), foi em 8 de março de 1984 que a OMA fez sua primeira manifestação, reunindo cerca de 500 mulheres em Itaberaba, distrito de Chapecó, Santa Catarina. A região em questão vivia na época a modernização da agricultura, com diversas transformações na forma de produção e na perda da autonomia de todo processo produtivo, que resultou na crise do modelo de produção agrícola tradicional e levou ao fortalecimento da industrialização e da integração do pequeno produtor rural às agroindústrias (ADÃO, 2011). No mesmo periodo as pastorais da igreja promoviam a conscientização de homens e mulheres sobre os papéis a serem desempenhados no ambiente doméstico e na sociedade, estimulando o surgimento de movimentos sociais com visões mais igualitárias, não necessariamente mais equitativas.

A realidade rural foi responsável pela movimentação das mulheres rurais. Entre seus componentes, a implementação dos pacotes tecnológicos e

\footnotetext{
4 O OMA altera seu nome em 1986 para Movimento de Mulheres Agricultoras e em 2004, com amplitude nacional, se consolida como Movimento de Mulheres Camponesas (MMC).
} 
O movimento de mulheres camponesas na construção do feminismo camponês popular | Débora $F$. dos Santos \& Silvia Aparecida Zimmermann

a integração de pequenos agricultores às agroindústrias tinham impacto imediato no meio rural e nas suas vidas.

[...] esses aspectos colocaram como pilares fundamentais, no caso do $\mathrm{MMC} / \mathrm{SC}$, que muito contribuiu para que a semente feminista camponesa fosse ganhando forma, organicidade e visibilidade social....Foi com a igreja que a mulher começou ser liderança, que foi abrindo espaço. Tem a igreja tradicional, mas também libertadora. Aî se iniciou as reuniões (CEC, Adélia, São Miguel D’Oeste/SC, 2017 apud GASPARETTO, 2017, p. 103).

Este artigo está organizado em cinco seções. A primeira seção descreve as primeiras experiências de mobilização do movimento feminista camponês. A segunda traz a história de vida e de luta de duas entrevistadas que evidenciam a estreita relação entre trajetória de vida, a constituição e ascensão de movimentos autônomos de mulheres rurais. A terceira seção traz as articulações e relações do movimento feminino camponês com outros movimentos de mulheres rurais. A quarta seção apresenta o feminismo camponês popular de forma mais detalhada. E finalmente, nas considerações finais fazemos uma reflexão sobre o Feminismo Camponês Popular ser uma construção em andamento e escrito pelas mulheres rurais em seus cotidianos.

\section{Primeiros passos do Feminismo Camponês Popular}

Em 1984, as mulheres rurais começaram a organizar-se para expandir o alcance do movimento até as demais localidades da região oeste de Santa Catarina. Assim, buscavam alcançar mais mulheres e revelar suas capacidades como sujeitos históricos em que a transformação conjuntural se fez de forma progressiva e gradual, acompanhado as conquistas do movimento em conjunto às transformações sociais (ADÃO, 2011).

Sendo um movimento social surgido com fortes laços com organizações religiosas, a OMA caracteriza-se em primeiro momento por sua conotação católica e inspira-se em exemplos de mulheres da Bíblia (MENDES; MUNARINI, 2007) para traçar novas formas de valorização nas relações familiares, destinando direitos e deveres à todos os integrantes da família, não sobrecarregando a figura materna da família. Essas leituras inspiraram comportamentos libertários e propuseram uma ótica questionadora dos valores patriarcais. Assim, as mudanças suscitadas eram comportamentais, de valorização e redistribuição de funções, mas não estruturais. 
O movimento de mulheres camponesas na construção do feminismo camponês popular | Débora $F$. dos Santos \& Silvia Aparecida Zimmermann

Outras mudanças foram relatadas por Gaspareto (2017):

A OMA perdurou até o ano de 1986, quando, a partir daí, as mulheres foram se dando conta de que uma organização não seria suficiente para responder às demandas que despontavam em suas lutas e que estavam no porvir. A partir de discussões, estudo, debates, em Assembleia, no ano de 1986, foi criado o MMA/SC. As deliberações daquela Assembleia giraram em torno da organicidade desse jovem Movimento (GASPARETO, 2017, p. 108).

A articulação com outros movimentos regionais foi realizada ainda no início dos anos 1980, com a instituição da Articulação dos Movimentos de Mulheres Trabalhadoras Rurais do Sul (AMMTR-SUL), envolvendo os estados do Paraná, Santa Catarina, Rio Grande do Sul, Mato Grosso do Sul e São Paulo, e os seguintes movimentos: Movimento de Mulheres Agricultoras (MMA); Organização de Mulheres Agricultoras de Mato Grosso do Sul; Movimento de Mulheres do Movimento Sem Terra do Estado de São Paulo; Movimento de Mulheres Trabalhadoras Rurais do Rio Grande do Sul; Comissão de Mulheres Trabalhadoras Rurais do Departamento Rural da CUT do Paraná (vinculada ao Movimento Popular de Mulheres do Paraná - MPMP) (GADELHA, et al., 2017, p.188).

Em 1986, no $1^{\circ}$ Encontro Nacional de Trabalhadoras Rurais realizado em Barueri, São Paulo, que contou com a presença de representantes de 16 estados, a antiga AMMTR-SUL passou a ser chamada de Articulação de Instâncias de Mulheres Trabalhadoras Rurais do Sul (AIMTR-SUL), com a participação exclusiva dos estados da região sul (PR, SC e RS) para fortalecer os movimentos de mulheres rurais nas diferentes regiões. Buscava-se, com isto, avançar na luta e aprofundar as discussões sobre sexualidade, reprodução, gênero, reconhecimento profissional, violência contra as mulheres, a partir da realidade das mulheres dessa região (GASPARETO, 2017).

A $1^{\mathrm{a}}$ manifestação pública do MMA foi realizada em 12 de agosto de 1986 na cidade de Xanxerê, em Santa Catarina. Essa reuniu mais de dez mil pessoas, na maioria mulheres, para reivindicar seus direitos, entre eles a aposentadoria aos 55 anos para as mulheres e 60 para os homens e o salário maternidade (FIGURA 1). Na ocasião, o abaixo assinado realizado na 
O movimento de mulheres camponesas na construção do feminismo camponês popular | Débora $F$. dos Santos \& Silvia Aparecida Zimmermann

manifestação foi encaminhado para Brasília5, no ano seguinte, 1987, consolidou-se uma atuação expressiva das mulheres trabalhadoras rurais na luta para garantia do reconhecimento profissional, salário maternidade e aposentadoria (MARTINS; BRUNETTO, 2014).

\section{Figura 1 - $1^{a}$ manifestação do Movimento de Mulheres Agricultoras (MMA) organizadas em Xanxerê, SC, em 12 de agosto de 1986}

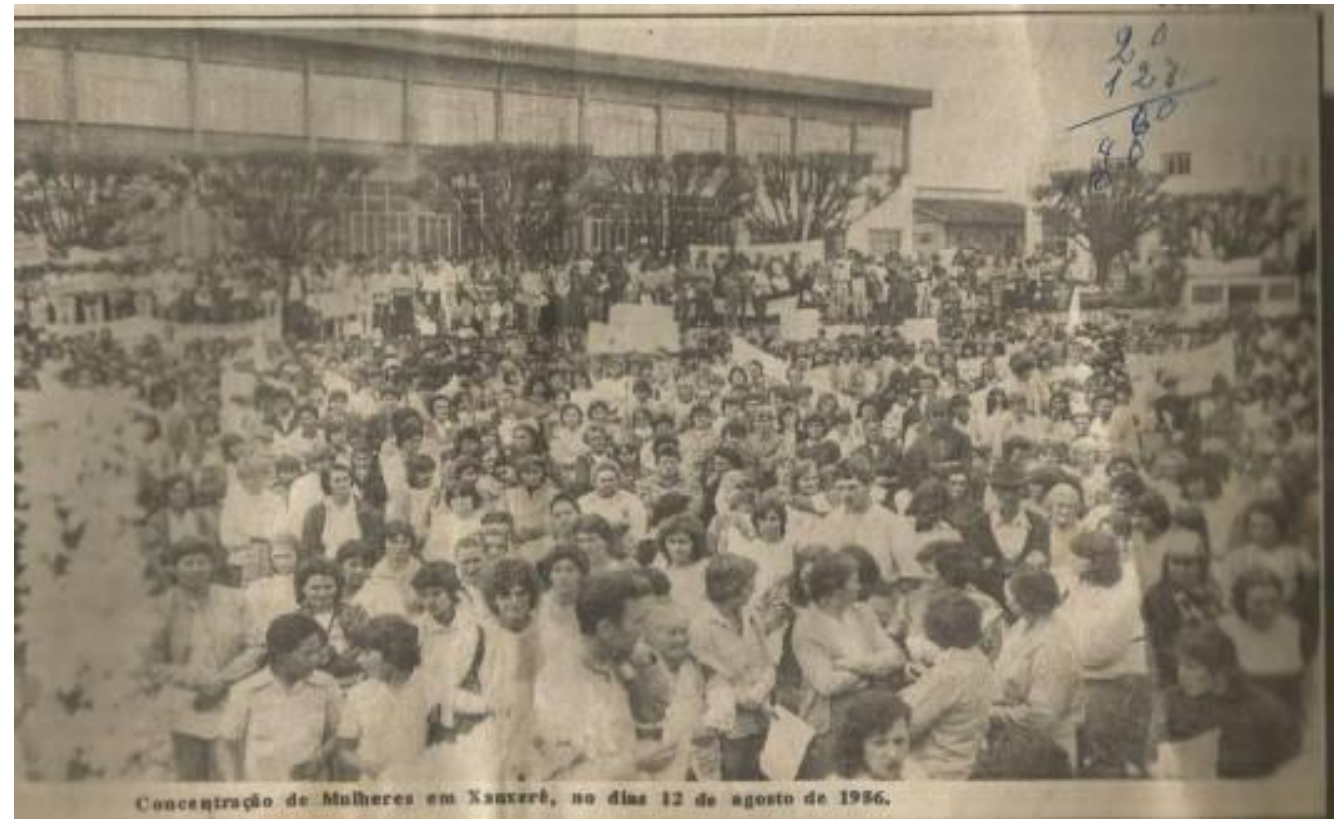

Fonte: MARTINS; BRUNETTO (2014, p. 111).

Apesar dos direitos garantidos às mulheres constarem na Constituição Federal de 1988, na prática, esses começaram a ser implementados no início da década de 1990, com o apoio de campanhas de conscientização promovidas pela AIMTR-SUL, como a aposentadoria aos 55 anos para a mulher, e aos 60 anos para os homens trabalhadores rurais, no ano de 1991; o beneficio por acidente de trabalho, em 1992 e o salário maternidade, em 1994. Ainda em 1994, o AIMTR-SUL lança a Campanha de Documentação pessoal e profissional "Nenhuma Trabalhadora Rural Sem Documentos”, divulgando uma cartilha em todo território da região sul, com informações sobre os direitos civis e a importância da documentação completa para alcançar a cidadania plena das mulheres trabalhadoras rurais. A cartilha também

\footnotetext{
5 Esse, teria colaborado, junto a outros documentos e reivindicações, para o documento final da Constituição Brasileira de 1988.
} 
O movimento de mulheres camponesas na construção do feminismo camponês popular | Débora $F$. dos Santos \& Silvia Aparecida Zimmermann

versava sobre os documentos necessários para o acesso aos direitos trabalhistas e previdenciários (GASPARETO, 2017, p.110).

Em conjunto com as reivindicações trabalhistas e previdenciárias, ainda no final dos anos 1980, o então MMA vê a necessidade de conquistar maior autonomia em relação às instituições, como sindicatos, movimentos sociais mistos e igrejas e, também, buscar espaços formativos exclusivos de mulheres para discussão de questões específicas, como a existência de conflitos relacionados à concepção de feminismo entre as mulheres do movimento, as realidades vividas para maior reconhecimento entre elas, entre outras questões. Assim, inicia-se a construção de novos objetivos, entre estes a capacitação de lideranças mulheres com acúmulos teóricos em temáticas que lhes interessavam (BETTO; PICCIN, 2017) e a construção de construção de um novo feminismo pelas mãos das camponesas.

Durante toda a década de 1990, as bandeiras mobilizadoras das mulheres trabalhadoras rurais foram centradas na luta pela sindicalização, pelo reconhecimento da profissão de trabalhadora rural e pela efetivação dos direitos previdenciários. Em 1994, o MMA encampou uma articulação na América Latina, participando da primeira reunião de conformação da Coordenação Latino Americana das Organizações do Campo (CLOC) ${ }^{6}$, realizada na cidade de Lima, no Peru. Ambos os movimentos têm participação ativa em todos os encontros realizados até o presente.

Como encaminhado na primeira reunião da CLOC, e após o esmorecimento da articulação, em 1995 é criada a Articulação Nacional de Mulheres Trabalhadoras Rurais (ANMTR), reunindo mulheres de vários movimentos mistos e autônomos, a Comissão Pastoral da Terra (CPT), o Movimento dos Trabalhadores Rurais Sem Terra (MST), a Pastoral da Juventude Rural (PJR), o Movimento dos Atingidos pelas Barragens (MAB), alguns Sindicatos de Trabalhadores Rurais e o Movimento dos Pequenos Agricultores (MPA).

Nos dias 19 a 24 de outubro de 1995, tendo como lema: Mulher Trabalhadora rural: Amante da Igualdade... é preciso ter força, é preciso ter garra, sempre, foi consolidada a ANMTR como espaço de discussão, elaboração e unificação das lutas. Fazem parte da ANMTR movimentos autônomos, coletivos de mulheres dos movimentos

${ }^{6} \mathrm{~A}$ CLOC possui compromisso constante com a luta social de movimentos campesinos, de trabalhadores e trabalhadoras, indígenas e afrodescendentes de toda América Latina e Caribe, constituída por 84 organizações em 18 países (CLOC, 2010). 
O movimento de mulheres camponesas na construção do feminismo camponês popular | Débora $F$. dos Santos \& Silvia Aparecida Zimmermann

mistos e pastorais (MMC, 1997, p. 3 apud GASPARETTO, 2017, p. 111).

Em 2001, o ANMTR lança uma cartilha com a campanha "Nenhuma Trabalhadora Rural sem Documentos" com repercussão nacional, reflexo do resultado positivo da campanha do AIMTR-SUL, lançada em 1994, com a mesma denominação. Esse documento foi elaborado de forma lúdica, e para além de informações sobre os comprovantes necessários para a retirada dos documentos para as conquistas de direitos básicos e a importância e discriminação das mulheres na sociedade, igualmente ressaltava o objetivo da ANMTR, deixando claro sua vertente feminista (sem essa denominação expressa) e classista.

[...] articular os Movimentos de Mulheres Autônomas e os coletivos de gênero de todos os movimentos sociais do campo. Surgiu da necessidade das próprias mulheres e constitui-se num espaço de ação em função da problemática vivida pelas mulheres trabalhadoras rurais. Busca contribuir para as mudanças das relações sociais de gênero e de classe (ANMTR, 2001, p. 2 apud GADELHA et al., 2017, p. 190).

No estado de Santa Catarina, entre 2003 e 2004, o MMA realizou caravanas, concentrações, marchas, mobilizações, congressos estaduais, entre outras práticas centrais na transição de Movimento de Mulheres Agricultoras de Santa Catarina para o Movimento de Mulheres Camponesas de Santa Catarina. No âmbito nacional, foi realizado, entre os dias 21 a 24 de setembro de 2003, um curso nacional com 50 representantes de movimentos autônomos de 14 estados brasileiros, um espaço de construção da identidade camponesa e de resolução da nomeação do movimento como Movimento de Mulheres Camponesas (GADELHA et al., 2017).

Em 2004, no âmbito brasileiro, o Congresso Nacional de Consolidação do MMC foi realizado em Brasília, no período de 05 a 08 de março de 2004 (FIGURA 2), "após intenso processo de estudo com dirigentes e grupos de base em 19 estados" (MMC/SC, 2008, p.19), quando ocorreu a participação efetiva no encontro de mais de 1400 mulheres de 14 estados (GADELHA et al., 2017). Nesse encontro foi definido que as mulheres camponesas são quem produz o alimento e garantem a subsistência da família, negras e brancas, pobres e nem tão pobres assim, pequenas agricultoras, pescadoras artesanais, quebradeiras de coco, extrativistas, arrendatárias, meeiras, ribeirinhas, posseiras, boias-frias, diaristas, parceiras, sem-terra, acampadas e 
O movimento de mulheres camponesas na construção do feminismo camponês popular | Débora $F$. dos Santos \& Silvia Aparecida Zimmermann

assentadas, assalariadas rurais e indigenas (MMC, 2004). Um dos principais fatores para a transição de identificação de trabalhadoras rurais para camponesas está na lógica do assalariamento. Muitas mulheres rurais não recebem salário, mas dependem do próprio trabalho produtivo para a garantia do alimento saudável, das plantas medicinais, do serviço doméstico, etc. que garantem a sobrevivência e a reprodução social de suas famílias.

\section{Figura 2 - $1^{\circ}$ Congresso Nacional do MMC, realizado em Brasilia em 2004}

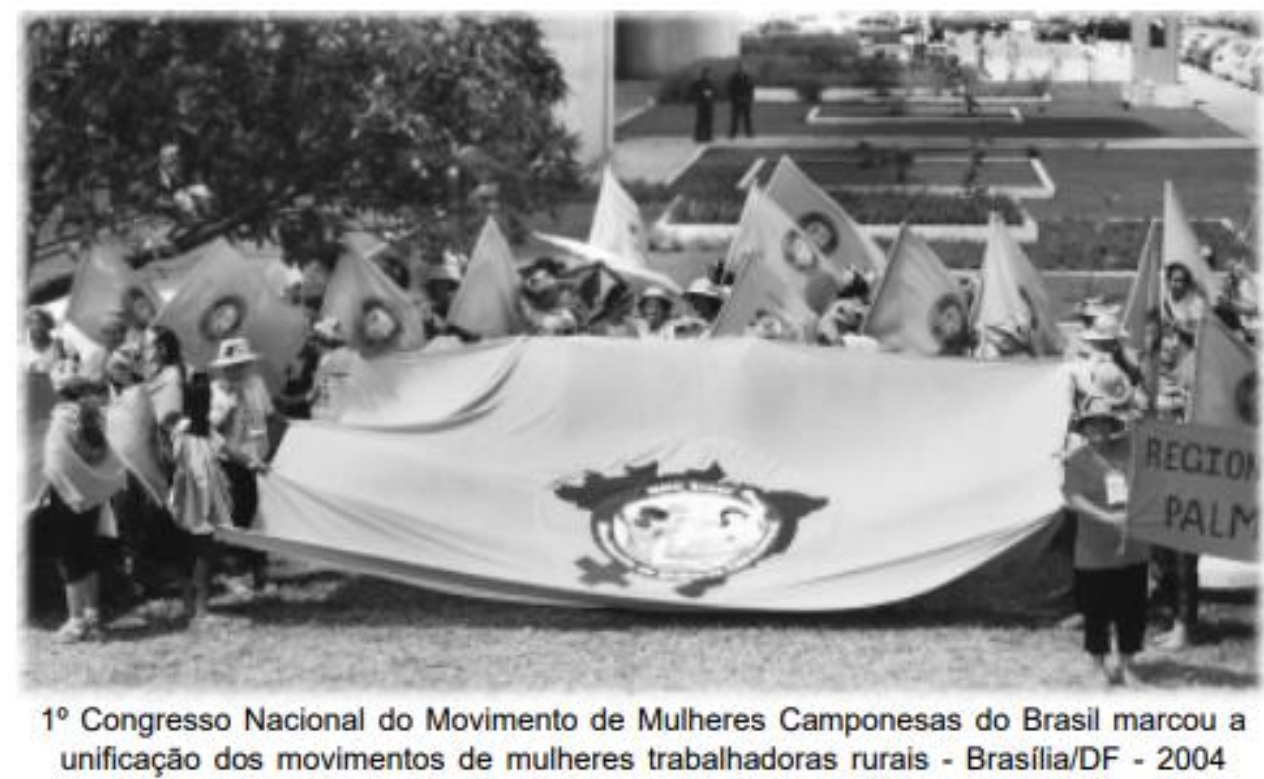

Fonte: Cartilha "Nenhuma Trabalhadora Rural sem Documentos" (MMC, 2004).

Com a realização da IX ${ }^{\mathrm{a}}$ Assembleia Estadual, em novembro de 2004, o MMA/SC assume definitivamente o caráter de um movimento constituído por mulheres camponesas, reconhecido oficialmente como Movimento de Mulheres Camponesas no estado de Santa Catarina, e posteriormente no plano nacional. Na prática o MMC intensificou o debate e a luta em torno do Projeto de Agricultura Camponesa Ecológica centrado no Programa das Sementes Crioulas e Hortaliças, que, por intermédio de intercâmbios, passa a dialogar com outras experiências de mulheres de diferentes regiões do Brasil e do exterior (ADÃO, 2011). Este Projeto se opõe à venda de sementes transgênicas, à utilização de insumos químicos e mão de obra infantil e escrava na produção de alimentos, à desvalorização do trabalho das mulheres, a estrangeirização e concentração da terra, e à padronização de atividades que 
O movimento de mulheres camponesas na construção do feminismo camponês popular | Débora $F$. dos Santos \& Silvia Aparecida Zimmermann

resultam em desmatamento, desequilíbrio ecológico, exploração no campo, insegurança alimentar e êxodo rural, entre outras questões.

\begin{abstract}
A luta central do MMC é contra o modelo capitalista e patriarcal e pela construção de uma nova sociedade com igualdade de direitos. Nesse sentido, assumimos como principal bandeira de luta o Projeto de Agricultura Camponesa Ecológica, com uma prática feminista, fundamentado na defesa da vida, na mudança das relações humanas e sociais e na conquista de direitos (MMC Lutas, site oficial, último acesso 09/08/2019).
\end{abstract}

Destaca-se que o Programa de Sementes Crioulas e Hortaliças não surgiu de um momento para o outro, mas foi produto de muitas discussões nos encontros realizados no início dos anos 2000 pelo MMC. Dentre a conformação da luta pelo Projeto de Agricultura Camponesa Ecológica e na perspectiva regional de inserção do pacote tecnológico com as sementes transgênicas, as mulheres assumiram a defesa das sementes crioulas, das variedades de hortaliças, das leguminosas, das flores e plantas medicinais, como método de subsistência frente à conformação do livre mercado e de suas consequências diretas sobre suas vidas.

Em 2003 a Via Campesina ${ }^{7}$ e a CLOC, em conjunto com os movimentos sociais associados e as experiências práticas das mulheres do MMC, lançaram no Fórum Social Mundial, realizado em Porto Alegre, no Rio Grande do Sul, a campanha "Sementes Patrimônio dos Povos a Serviço da Humanidade". O objetivo da mesma era garantir o direito da agricultura familiar camponesa de produzir suas próprias sementes, bem como garantir a soberania alimentar e o impedimento da dominação das transnacionais sobre o controle das variedades, produção e comercialização de sementes (CAMPANHA DA VIA CAMPESINA INTERNACIONAL, 2012).

Um dos atos que marcou a luta dos movimentos populares brasileiros, e em que as mulheres do MMC foram protagonistas, ocorreu na madrugada do dia 08 de março de 2006, no municipio de Barra do Ribeiro no Rio Grande do Sul, onde 40 ônibus com mais de 2 mil mulheres da Via campesina adentraram o Horto Florestal da Fazenda Barba Negra, de propriedade da empresa Aracruz Celulose, e destruíram um milhão de mudas de eucalipto

\footnotetext{
7 Os movimentos sociais que participam da Via Campesina são: o MMC, o MAB, o MST, a Comissão Pastoral da Terra (CPT), a Federação Brasileira de Estudantes de Agronomia (FEAB) e o Movimento de Pequenos Agricultores (MPA).
} 
O movimento de mulheres camponesas na construção do feminismo camponês popular | Débora $F$. dos Santos \& Silvia Aparecida Zimmermann

prontos para plantação. A mobilização trazia a frase "não ao deserto verde", fazendo alusão aos milhares de hectares na América Latina destinados à produção de apenas uma cultura de eucalipto, pinos e acácias para a produção de celulose, resultando na destruição da biodiversidade, em fontes de água secas e a poluição deixada pelas indústrias de celulose (MANO, 2010).

Paralelo a esse evento, Porto Alegre sediava outros dois: a II Conferência Internacional sobre Reforma Agrária e Desenvolvimento Rural da Organização das Nações Unidas para Alimentação e Agricultura (FAO) e o Fórum Terra, Território e Dignidade, ambos na Pontificia Universidade Católica do Rio Grande do Sul (PUC-RS). Após a manifestação na Empresa Aracruz Celulose as mulheres marcharam dois quilômetros até o local dos eventos, em Porto Alegre, quando foram barradas pela Polícia Militar. Após negociações, as mulheres foram autorizadas a entrar. Duas representantes, uma do MMC e outra do MST, leram o Manifesto das Mulheres Camponesas para as 81 delegações estrangeiras participantes do evento da FAO e foram aplaudidas de pé (MANO, 2010). Abaixo segue um quadro síntese das principais ações dos movimentos de mulheres rurais na região sul e sudeste do país, desde os anos de 1980. Destaca-se que as atividades entre 2015 e 2017 serão melhor detalhadas no próximo item.

\section{Quadro 1 - Sintese das principais ações e articulações de movimentos autônomos de mulheres rurais, anos 1980 até 2017}

Início dos anos > Articulação dos Movimentos de Mulheres Trabalhadoras Rurais do Sul 1980 (AMMTR-SUL) com PR, SC, RS, MS e SP.

1983 > Criação da Organização de Mulheres Agricultoras (OMA), oeste SC.

1984 08/03 - Dia da Mulher, $1^{\text {a }}$ Manifestação OMA, reuniu 500 mulheres, em Chapecó, SC.

1986 > I Encontro Nacional das Trabalhadoras Rurais, SP. Consolidação ANMTR;

$>$ De AMMTR-SUL para AIMTR-SUL;

Transição de OMA para Movimento de Mulheres Agricultoras (MMA); $>12 / 081^{a}$ Manifestação Pública MMA.

$1988>$ II Encontro Nacional das Trabalhadoras Rurais, SP. Coordenação Nacional de Trabalhadoras Rurais;

> Participação da ANMTR na elaboração da Constituição Brasileira, conquista de direitos previdenciários (teoria).

\begin{tabular}{cl}
\hline Final dos anos & $>$ ANMTR com a CUT institui a Comissão Nacional da Questão da Mulher \\
1980 & Trabalhadora Rural. \\
\hline 1991 & $>$ Campanha da ANMTR “Trabalhadora Rural Declare sua Profissão" para \\
& realização do Censo IBGE; \\
& $>$ Direito à aposentadoria conquistada na prática. \\
\hline 1992 & $>1^{\circ}$ Encontro Nacional das Mulheres Trabalhadoras da CUT, SP;
\end{tabular}


O movimento de mulheres camponesas na construção do feminismo camponês popular | Débora $F$. dos Santos \& Silvia Aparecida Zimmermann

$>$ Beneficiamento por acidente de trabalho na prática.

\begin{tabular}{|c|c|}
\hline 1994 & $\begin{array}{l}\text { > Campanha da AIMTR-SUL de documentação "Nenhuma Trabalhadora } \\
\text { Rural sem Documentos"; } \\
\text { > Salário Maternidade conquistado na prática; } \\
\text { > MMA participa da } 1^{a} \text { reunião da CLOC, encaminha-se a formação da } \\
\text { ANMTR. }\end{array}$ \\
\hline 1995 & $\begin{array}{l}\text { > Criação da Articulação Nacional de Mulheres Trabalhadoras Rurais } \\
\text { (ANMTR), com participação das mulheres de movimentos mistos e } \\
\text { autônomos. }\end{array}$ \\
\hline 2001 & $\begin{array}{l}\text { > Campanha nacional "Nenhuma Trabalhadora Rural sem Documentos" da } \\
\text { ANMTR. }\end{array}$ \\
\hline 2003 & $\begin{array}{l}\text { > Curso Nacional, reunião de } 50 \text { mulheres de } 14 \text { estados, originou-se a } \\
\text { denominação MMC. }\end{array}$ \\
\hline 2004 & $\begin{array}{l}\text { > Congresso Nacional de Consolidação do MMC, Brasília; } \\
\text { > MMA consolida-se como Movimento de Mulheres Camponesas (MMC) no } \\
\text { estado de Santa Catarina. }\end{array}$ \\
\hline 2006 & $\begin{array}{l}>08 / 03 \text { Ação de } 2 \text { mil mulheres da Via Campesina contra a Aracruz Celulose, } \\
\text { destruição de } 1 \text { milhão de mudas de eucalipto. }\end{array}$ \\
\hline 2007 & $\begin{array}{l}\text { > Consolidação do Fórum Itinerante das Mulheres em Defesa da Seguridade } \\
\text { Social (FIPSS), Brasília, com participação dos movimentos de mulheres } \\
\text { rurais; } \\
\text { > 08/03 Lançamento da Campanha Nacional pela Produção de Alimentos } \\
\text { Saudáveis (CNPAS). }\end{array}$ \\
\hline 2015 & $\begin{array}{l}\text { > I Seminário Internacional com o tema: Feminismo Camponês e Popular, } \\
\text { Luziânia, GO. }\end{array}$ \\
\hline 2016 & $\begin{array}{l}\text { > II Seminário Internacional Feminismo Camponês e Popular, Luziânia, GO. } \\
\text { Somam-se mulheres PY, Chile e Moçambique. }\end{array}$ \\
\hline 2017 & > III Seminário Feminismo Camponês Popular, Luziânia, GO. \\
\hline
\end{tabular}

Tornou-se habitual, desde o início do MMC, a retomada de saberes e práticas das camponesas na construção do próprio movimento ressignificando-os com o passar dos anos. Um dos exemplos é o Projeto Popular de Agricultura Agroecológica ${ }^{8}$, baseado no cultivo e reprodução de sementes crioulas, na socialização de conhecimento entre as camponesas, na utilização de plantas medicinais, na alimentação saudável, nos projetos de quintais produtivos para localidades menores e urbanas, na luta contra a violência física, psicológica, simbólica, verbal, patrimonial etc. Todas essas ações são direcionadas às mulheres, com intuito de valorizar a participação dessas em cargos de direção e espaços de tomada de decisão, entre outras ações, todas baseadas na perspectiva feminista de vida camponesa e na ressignificação dos ensinamentos passados de geração a geração.

\footnotetext{
8 Com a introdução da noção agroecológica, utiliza-se ecológico para citar o modo de vida agroecológico.
} 
O movimento de mulheres camponesas na construção do feminismo camponês popular | Débora $F$. dos Santos \& Silvia Aparecida Zimmermann

Diante disso, percebe-se que a preocupação com a alimentação saudável da família é fundamental no estilo de vida camponês, e as funções de produção, preparo e finalização dos alimentos são historicamente atribuídas às mulheres. Nas práticas do MMC a mulher camponesa é prestigiada e enaltecida também pela analogia mulher-terra, dentro de uma teoria ecofeminista ${ }^{9}$, que entende ambos como produtores de alimentos e geradoras de vida. Essas relações são simbolizadas e legitimadas pelas práticas agroecológicas de cuidado a vida e da natureza, realizadas individualmente ou em conjunto às histórias de vidas das mulheres participantes do MMC. Contudo, a crise sobre a valorização e o cuidado na contemporaneidade ${ }^{10}$ ultrapassa as delimitações de urbano e rural, e afeta toda a sociedade. Seres humanos necessitam de cuidados durante toda sua existência, e esse é essencial para a reprodução social das famílias, principalmente as famílias rurais, contudo, seu compartilhamento é necessário com as figuras masculinas, como também precisa ser valorizado e valorado por toda sociedade, principalmente pelas politicas públicas sociais.

Isso posto, o acúmulo reunido pelas mulheres rurais nos movimentos mistos e no MMC reafirmou sua luta em dois eixos: Gênero e Classe. Gênero porque os movimentos autônomos de mulheres rurais são constituídos, pensados, organizados e concretizados por mulheres rurais para mulheres rurais; e Classista porque em conjunto ao enfrentamento do patriarcado também há o enfrentamento ao capitalismo desenfreado, sistema esse que sustenta o machismo e o faz perpetuá-lo. Dessa forma, entende-se que são as trabalhadoras e os trabalhadores rurais que lutam pela igualdade e equidade, e com isso foi proposto uma mística feminina, feminista e libertadora, expressa no Feminismo Camponês Popular, a partir do qual o MMC compromete-se a transformar as relações sociais de classe com a mudança nas relações com a natureza e na construção de novas relações sociais de gênero.

\footnotetext{
9 A teoria ecofeminista possui várias vertentes, as mais conhecidas são: ecofeminismo clássico, ecofeminismo espirituais (Yvone Gebara e Vandana Shiva) e ecofeminismos construtivistas (Bina Agarwal e Val Plum Wood).

10 A discussão sobre a crise do cuidado na contemporaneidade originou-se no seminário Soberania Alimentar e o protagonismo das mulheres na construção da agroecologia no $17^{\mathrm{a}}$ Jornada de Agroecologia, que aconteceu entre os dias 6, 7, 8 e 9 de junho de 2018 em Curitiba, Paraná. A autora esteve presente no evento e acompanhou os debates sobre o tema.
} 
O movimento de mulheres camponesas na construção do feminismo camponês popular | Débora $F$. dos Santos \& Silvia Aparecida Zimmermann

\section{História de Vida e Luta - Mulheres em Movimento}

O histórico de vida e atuação política das entrevistadas expõe duas experiências pessoais de mulheres e dirigentes nacionais do movimento autônomo de mulheres rurais (no caso o MMC), com perfis distintos, amalgamadas na luta pelos direitos das mulheres rurais, contra o patriarcado, o capitalismo e a modernização desigual da agricultura.

A Eloisa ${ }^{11}$ iniciou sua militância com a participação na Pastoral da Juventude Rural (PJR). Ela era representante da Pastoral no Grupo de Juventude do Sindicato Rural do município de Salgado Filho, Paraná, onde conheceu seu companheiro, também envolvido no sindicalismo rural.

[...] desde 1998 eu comecei participando primeiro da pastoral da juventude, depois da Comissão de Jovens do sindicato em Salgado Filho-PR.[..] Eu iniciei na Pastoral da Juventude Rural, que não denominava-se assim, mas era a Pastoral da Juventude, vinculada à Igreja Católica que atuava na comunidade rural em que viviamos, depois quando conheci o meu companheiro envolvido no sindicato até a raiz do cabelo, comecei a participar do grupo de jovens do sindicato, quando casamos em 1998, participei da comissão de mulheres do sindicato de trabalhadores rurais de Salgado Filho (Eloisa, 22 maio de 2018).

Em 1998 foi criado o Sindicato Rural de Salgado Filho e a Eloisa foi convidada a fazer parte da Comissão das Mulheres no Sindicato. Relata que nas reuniões com as mulheres eram encaminhadas pautas e demandas à direção do Sindicato, de forma que era gerada uma expectativa de serem acatadas as demandas das mulheres. Contudo, conta que os homens ocupavam exclusivamente os cargos de direção do Sindicato Rural de Salgado Filho (comum na maioria dos sindicatos rurais do Brasil à época), e quando as pautas das mulheres eram discutidas, não se verificava o seguimento das recomendações, causando um sentimento de frustração nas mulheres.

Na Comissão de Mulheres do Sindicato Rural de Salgado Filho-PR fazíamos as atividades, as reuniões do grupo, pautava questões, definimos, gerava expectativa, mas quando chegava na direção do sindicato muita coisa não se efetivava. Porque numa sociedade patriarcal, sempre nos espaços de decisão das nossas organizações do campo inclusive, a maioria absoluta são homens. E quando as mulheres estão nesses espaços de decisão muitas vezes estão lá mas são sub representadas, a voz da mulher não tem o mesmo peso que do homem, e muitas vezes quando estão nesses espaços ocupam funções de tarefeiras, articular e organizar a reunião, chamar todos para a reunião, fazer relatórios, etc., essa é a realidade e função das mulheres, de ocuparem essas tarefas (Eloisa, 22 maio de 2018).

\footnotetext{
11 Nome fictício para preservar a imagem da entrevistada.
} 
O movimento de mulheres camponesas na construção do feminismo camponês popular | Débora $F$. dos Santos \& Silvia Aparecida Zimmermann

Muitas vezes às militantes eram destinadas as funções de tarefeiras, como a relatoria das reuniões, o servir café, o cuidado com a limpeza, entre outros trabalhos corriqueiramente destinados ao público feminino. Com a inserção e participação mais efetiva das mulheres, numa conformação predominantemente masculina dos movimentos mistos e sindicatos rurais, intensificaram-se as tensões entre gêneros. As mulheres passaram a perceber a condição de marginalização que vivenciavam nas organizações políticas e sociais, assim como a dominação sofrida nos âmbitos público e doméstico.

Em mudança para Medianeira, no oeste do Paraná, no início dos anos 2000, a Eloisa ficou um tempo afastada dos movimentos sociais devido à frustração gerada com a experiência do último sindicato. Um tempo depois surgiu um convite para seu companheiro trabalhar no Sindicato de Trabalhadores Rurais de Medianeira, e é através deste sindicato ocorreu uma ponte entre o $\mathrm{MMC}^{12}$ e as mulheres rurais da região oeste do Paraná. Assim, ressalta a importância do sindicalismo no sul do país:

[...] o contato das mulheres camponesas das dirigentes era feito através dos sindicatos, hoje em dia está mais fácil com o acesso ao telefone celular, internet, mas naquele período os contatos eram através dos sindicatos, mandavam fax, e-mail, telefonar, mandar recado, chamar fulana, esperar o retorno da pessoa, receber os recados. Em muitos lugares ainda hoje, um exemplo é Dionísio Cerqueira em SC, que tem um programa de rádio do sindicato e que ele passa os recados, inclusive os chamados de reunião dos movimentos de mulheres. Isso foi em vários sindicatos que tinham essa abertura muito importante, então foi através do sindicato que tinha essa ponte que eu conheci o movimento de mulheres, na época articulação[...] (Eloisa, 22 maio de 2018).

A Eloisa graduou-se em 2013, em Pedagogia para Educadores do Campo pelo Programa Nacional de Educação na Reforma Agrária (PRONERA), na Universidade Estadual do Oeste do Paraná (UNIOESTE), localizada em Cascavel, Paraná; e concluiu o mestrado em 2019, em Sociedade, Cultura e Fronteiras, na UNIOESTE, campus de Foz do Iguaçu, Paraná. Tanto a graduação quanto o mestrado foram sobre estudos sobre as mulheres rurais, sendo o ulterior voltado à autonomia das mulheres na comercialização em feiras agroecológicas. Sua percepção frente à identidade feminista, conta

\footnotetext{
12 Destaca-se que na época o MMC era denominado Articulação Nacional de Mulheres Trabalhadoras Rurais (ANMTR), que no Paraná era representado pela Organização de Mulheres Trabalhadoras Rurais do Paraná (OMTR-PR).
} 
O movimento de mulheres camponesas na construção do feminismo camponês popular | Débora $F$. dos Santos \& Silvia Aparecida Zimmermann

Eloisa, "[...] aflorou após minha primeira participação como representante do MMC num curso de formação realizado em Passo Fundo, no Rio Grande do Sul, onde funcionava a Secretaria de Articulação Sul das Mulheres Trabalhadoras Rurais". Nesse espaço percebeu que se tratava de uma organização diferente, pensada, feita, organizada e coordenada pelas próprias mulheres, e que essas faziam parte desde o processo de discussão nos grupos de bases dos municípios, até o encaminhamento das discussões para os espaços de tomada de decisão, e nesses elas eram efetivamente ouvidas. Contudo, o reconhecimento desse processo como "feminismo", que engloba o histórico de luta do movimento de mulheres aconteceu mais tardiamente, relata a Eloisa, em 2007, com o acúmulo de ações, mobilizações e formações que o próprio MMC desenvolveu em conjunto com a construção do Feminismo Camponês Popular.

Já Bianca ${ }^{13}$ é nascida e residente no estado do Rio Grande do Norte. Ela iniciou sua formação política ainda na faculdade com atuação na Federação de Estudantes de Agronomia do Brasil (FEAB), onde teve contato e se simpatizou com as bandeiras de luta dos movimentos que compõem a Via Campesina Brasil. Formou-se em 2006, em Agronomia, pela Universidade Federal Rural do Semiárido (UFERSA). Formada atuou em assentamentos de reforma agrária com assistência técnica. Devido à sua referência de bandeiras de luta da Via Campesina sobre a questão agrária e as referências feministas durante a graduação, e com pretensões de unificação de lutas, aproximou-se do MMC, o qual fazia o debate político contra o agronegócio, o patriarcado e a dominação capitalista. Posteriormente, começou a atuar na base do MMC, que à época não estava presente no estado do Rio Grande do Norte, contudo, já contava com uma pequena organização na Paraíba, na Bahia, em Alagoas e Sergipe. Assim, assumiu a tarefa de construção da base no próprio estado, que não possuía nenhum movimento de mulheres rurais consolidado. Atualmente é dirigente nacional do MMC.

Quando questionada sobre sua percepção e reconhecimento sobre ser feminista, a Bianca ressalta que já se entendia como feminista anteriormente ao movimento. Disse ter sido justamente este fato que a uniu ao MMC e não a outro movimento, apesar de achar relevantes terem as bandeiras de luta dos

13 Nome fictício para preservar a imagem da entrevistada. 
O movimento de mulheres camponesas na construção do feminismo camponês popular | Débora $F$. dos Santos \& Silvia Aparecida Zimmermann

outros movimentos. Afirma que sua compreensão sobre feminismo foi qualificada com sua atuação no $\mathrm{MMC}$, com a construção do Feminismo Camponês Popular, um feminismo que valoriza a autonomia das mulheres, inclusive para que possam decidir por seguirem reproduções do conservadorismo.

Diferentemente da Eloisa, que reside no Sul do país, no Nordeste, como salienta a Bianca

[...] existem configurações locais, estruturais e biológicas que influenciam permanentemente as pautas do MMC na região. O debate de convivência com o semiárido ${ }^{14}$ é fundamental nos grupos de base do MMC no Nordeste, a escassez de água, o armazenamento, o abastecimento, construção de cisternas, acesso à mercados, etc., são pautas quase que diárias (Bianca, 21 junho de 2018).

Ela menciona que a desigualdade, a divisão sexual do trabalho e o patriarcado estão presentes, independente da região do país, seja no urbano, ou no rural local. Conforme relata, "enquanto mulheres rurais precisamos partir disso, do macro, da modificação dessa estrutura e isso passa pela visibilização da produção, reconhecimento profissional, valorização do modo de vida etc.".

Conforme salientado pelas entrevistadas existem particularidades nas regiões, culturas e histórias vividas por elas, mas o MMC busca a união na luta pela conquista da liberdade e autonomia das mulheres, isso é único e não varia de uma região para outra no Brasil.

\section{Articulações e Relações com outros Movimentos de Mulheres Rurais}

O MMC historicamente esteve articulado a outros movimentos sociais mistos e específicos na construção da democracia brasileira, na conquista por direitos à classe trabalhadora do campo e da cidade e na conquista pela liberdade das mulheres. A primeira Articulação Nacional de Mulheres Trabalhadoras Rurais, ressaltam as entrevistadas do MMC, aconteceu numa conjuntura de abertura política para a construção da democracia brasileira, resultando na consolidação da Constituição Federal de 1988. Nesse momento

\footnotetext{
14 O Semiárido brasileiro é composto por 1262 municípios, dos estados do Maranhão, Piauí, Ceará, Rio Grande do Norte, Paraíba, Pernambuco, Alagoas, Sergipe, Bahia e Minas Gerais. Os critérios para delimitação do Semiárido implicam baixa precipitação pluviométrica e déficit hídrico. A competência para fixar critérios técnicos e científicos para delimitação do Semiárido foi dada ao Conselho Deliberativo - CONDEL da Superintendência do Desenvolvimento do Nordeste - SUDENE pela Lei Complementar $n^{\circ}$ 125, de 3 de janeiro de 2007 (IBGE, site oficial, último acesso: 20/05/2019).
} 
O movimento de mulheres camponesas na construção do feminismo camponês popular | Débora $F$. dos Santos \& Silvia Aparecida Zimmermann

a articulação era constituída majoritariamente pelos movimentos autônomos de mulheres rurais, com uma menor participação de mulheres vindas de movimentos mistos. Após a conquista de direitos previdenciários e campanhas em todo território para colocá-los em exercício, a Bianca observa que houve um esfriamento na articulação. As razões do esfriamento são comentadas por ela:

[...]a gente sente que é muito difícil nas vida das mulheres essa continuidade na luta por longos períodos de forma ininterrupta, por que quando casam ou às vezes já são casadas e têm filhos pequenos, não conseguem ir, aí depois de uma certa idade que conseguem participar, então você vê pessoas, não necessariamente jovens, você vê muitas mulheres mais velhas, o MMC é um exemplo bem claro, só que tem periodos da vida delas que possuem maiores dificuldades de frequentar. (Bianca, 21 junho de 2018).

Num segundo momento de articulação, em 1995, a Articulação Nacional das Trabalhadoras Rurais teve como objetivo a união das bandeiras de mulheres rurais, conformada pelas mulheres de movimentos autônomos de mulheres rurais e de movimentos sociais rurais mistos. Ambas as entrevistadas relembram que com a chegada da Via Campesina no Brasil, em parceria com a CLOC, a articulação concretizou-se neste espaço e com a importante participação de mulheres camponesas, indígenas e afrodescendentes de toda América Latina.

[...] a gente começa se organizar na CLOC, que é a Via Campesina da América Latina, e também na Via Campesina, e nesse espaço surge essa outra articulação de 1995, que é uma articulação das mulheres, e essa articulação corria por dentro da Via, mas já era composta pelas mulheres das organizações que compunham a Via Campesina, é quase como uma consequência disso isso passar a ser uma organização por dentro da Via, sendo que a Via tem a tarefa de lidar com as diversas lutas camponesas a partir da soberania alimentar (Bianca, 21 junho de 2018).

Com a consolidação da articulação, as mulheres reúnem-se anteriormente para elencar as pautas que serão encaminhadas à reunião principal da Via Campesina em conjunto a CLOC. Mas esse espaço acabou esvaziado posto que as mulheres que participavam eram as mesmas dos movimentos autônomos, por isso, as entrevistadas salientam a construção da articulação autônoma que acontece atualmente no espaço da Via Campesina Brasil, e com a coordenação das mulheres dos movimentos de mulheres rurais. 
O movimento de mulheres camponesas na construção do feminismo camponês popular | Débora $F$. dos Santos \& Silvia Aparecida Zimmermann

Conforme o relato da Eloisa, em 2004, com a consolidação do MMC Brasil houve um diálogo realizado em todos os estados que possuíam movimentos sociais autônomos de mulheres, inclusive o MMTR-NE, que foram convidados para se somar à construção do MMC. Apenas o MMTR-NE não se somou ao MMC e, por este motivo que, ressalta Bianca “[...] na região Nordeste do Brasil há estados que se encontra o MMTR-NE e também o MMC”. O MMTR-NE foi criado em 1986, a partir de reflexões e intercâmbio de trabalhadoras rurais dos estados de Pernambuco e Paraíba, com o intuito de superar as dificuldades na relação de gênero que as mulheres rurais enfrentavam (MMTR NE, 2019). Conforme relata Bianca, o MMC e o MMTR$\mathrm{NE}$ são dois movimentos sociais diferentes, sem rixa aparente ou desentendimento entre dirigentes, contrariamente, há lutas e processos conjuntos.

Um exemplo dessa aproximação entre movimentos "distintos" é evidenciado pelo caso relatado pela Eloisa, "[...]com a consolidação do Fórum Itinerante das Mulheres em Defesa da Seguridade Social (FIPSS), criado em abril de 2007, em resposta à ausência da participação dos movimentos de mulheres (do campo e da cidade) no Fórum Nacional de Previdência Social (FNPS) criado pelo Governo Lula em 2007". Conta a entrevistada que somente uma representante do MMC que participava do Conselho Nacional do Direito das Mulheres (CNDM) conseguiu cadeira como ouvinte, sem direito à voz. Participaram do FIPSS, para além do MMC e MMTR-NE, a Articulação de Mulheres Brasileiras (AMB), a Campanha Nacional pelo Direito à Aposentadoria das Donas de Casa, a Articulação Nacional das Mulheres Negras (AMNB), a Federação Nacional de Trabalhadoras Domésticas (FENATRAD), o Movimento Interestadual das Quebradeiras de Coco Babaçu (MIQCB) e a Marcha Mundial das Mulheres (MMM).

O objetivo do FIPSS era o fortalecer a luta por direitos, contra a desproteção social das mulheres e ameaças políticas aos direitos conquistados com a Constituição Federal de 1988 de efetivação do caráter público, universal, solidário e redistributivo da seguridade Social no Brasil. Sendo alguns desses direitos já ameaçados desde os anos 1990, pelas duas reformas previdenciárias feitas em 1998 e 2003, pelos governos de Fernando Henrique 
O movimento de mulheres camponesas na construção do feminismo camponês popular | Débora $F$. dos Santos \& Silvia Aparecida Zimmermann

Cardoso e Lula15, consecutivamente, essas ameaças reforçaram a ideia de que só tem direito à aposentadoria quem contribui. Essa medida é um empecilho à inclusão das mulheres na Previdência Social, sendo que a maioria delas dedica-se aos trabalhos domésticos de cuidados sem qualquer reconhecimento formal e/ou financeiro. Grande parte dessas mulheres são empregadas domésticas informais ${ }^{16}$, como também de outros trabalhos informais, a exemplo as catadoras de lixo reciclável, vendedoras, parteiras, ambulantes, feirantes e inúmeras outras trabalhadoras, todas sem acesso à previdência (FREITAS; MORI; FERREIRA - org, 2010).

No período de 2007, realizaram “[...] mobilizações itinerantes em várias regiões do país denunciando que o verdadeiro problema da Previdência Social era sua divida social com milhões de trabalhadoras e trabalhadores desprotegidos pelo sistema" (FREITAS; MORI; FERREIRA, 2010, p. 38). Também foram realizadas atividades nacionais e regionais, em coordenação com os movimentos sociais parceiros, para a construção de propostas para a Previdência Social brasileira, com apoio de grupos e articulações de sociedade civil urbanas e rurais, do Governo, especialmente com a Secretaria Especial de Políticas para as Mulheres (SNPM). Em outubro de 2007, no momento em que se encerram as atividades do FNPS, as mulheres organizadas no FIPSS acamparam durante o evento na frente do Ministério da Previdência Social para entregar uma carta elaborada por elas diretamente ao Ministro na ocasião de encerramento do Fórum.

O FIPSS mantém-se até atualmente sob ameaça constante aos direitos das trabalhadoras e trabalhadores por parte dos governos e das empresas privadas, de maneira que são mobilizadas diversas ações em conjunto, mas principalmente, realizados acampamentos em frente aos locais dos eventos políticos de discussão dos interesses previdenciários e seguridade social. $\mathrm{Na}$ FIGURA 3 é apresentado um acampamento realizado em Brasília, em paralelo a I Conferência Mundial sobre Sistemas Universais de Seguridade Social, ocorrido em 2010.

\footnotetext{
15 Em 1998, através da PEC n 20/98 foi instituída a idade mínima para aposentadoria, 55 anos para mulheres e 60 anos para os homens. Já em 2003, a Emenda Constitucional n $41 / 03$ reforma visava estabelecer critérios de contribuição para o servidor público inativo e fixando a base de cálculo para a aposentadoria (Site oficial do Planalto, 1998;2003).

16 A maioria das 7 milhões de empregadas domésticas no Brasil são informais, sendo aquelas com carteira assinada 26,2\%, dessas apenas 30,4\% contribuem para a Previdência Social (FREITAS; MORI; FERREIRA - org, 2010).
} 
O movimento de mulheres camponesas na construção do feminismo camponês popular | Débora $F$. dos Santos \& Silvia Aparecida Zimmermann

\section{Figura 3 - Acampamento das mulheres participantes do FIPSS em Brasilia em 2010}

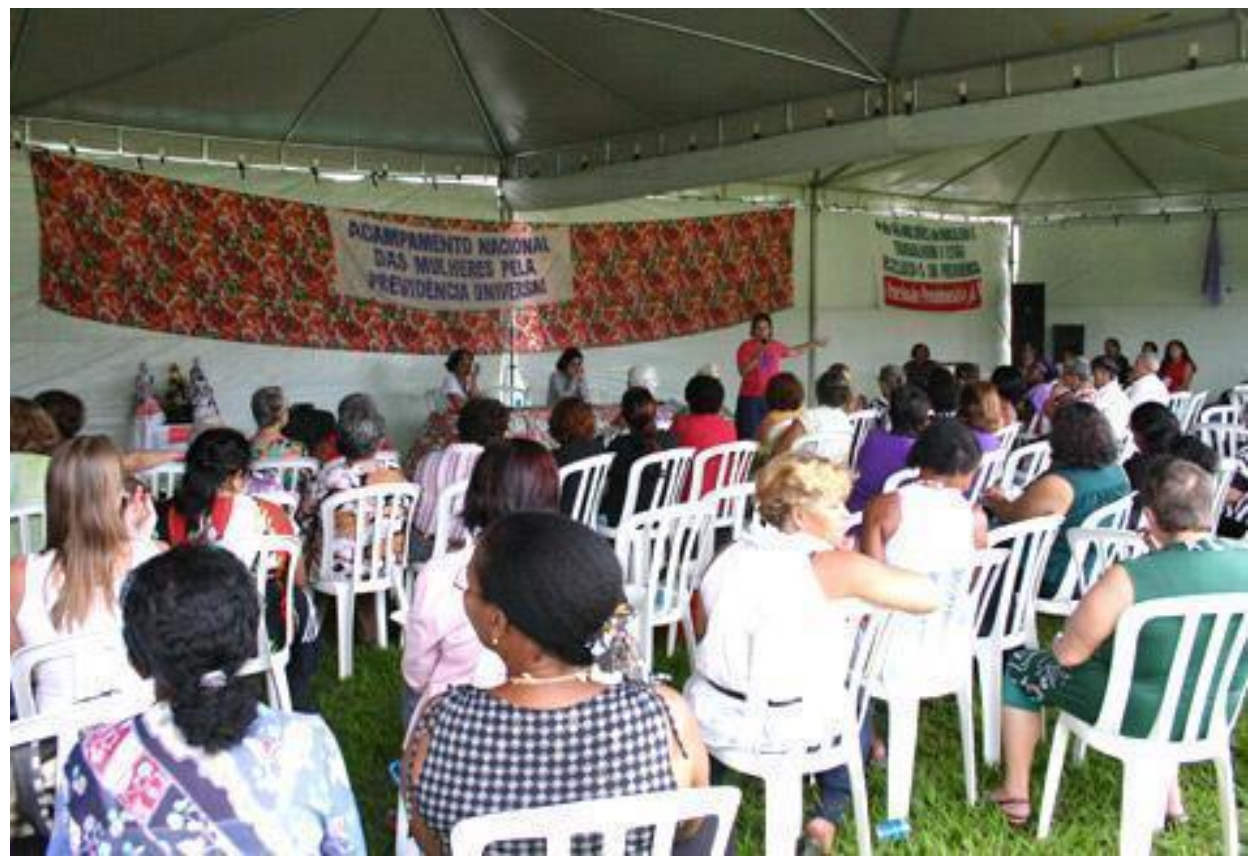

Fonte: Site oficial do Conselho Federal de Serviço Social (CFESS), 2010.

Esse momento pode ser lido com a força de articulação que as mulheres trabalhadoras rurais e urbanas possuem quando unificadas em prol de uma bandeira única. Muito além de considerá-los movimentos sociais divergentes, constata-se que o MMTR-NE e o MMC são movimentos sociais distintos, mas com bandeiras unificadas. Ressalta Bianca que "ambos os movimentos emergiram de regiões muito distintas, de contextos locais totalmente divergentes e acumularam através das décadas de atuação particularidades de luta, como no caso do MMC que a partir de 2004 amplia suas ações para todas as regiões brasileiras". Em outra situação está o MMTR$\mathrm{NE}$, com caráter mais regional e atuação concentrada.

\section{Feminismo Camponês Popular}

O Feminismo Camponês Popular (FCP) surge da necessidade de uma leitura própria do feminismo pelas mulheres camponesas, indígenas, negras, sem-terra, assentadas da Reforma Agrária, reassentadas, extrativistas, mulheres pobres e outras nem tanto, lésbicas, entre outras características que definem a diversidade das mulheres integrantes do MMC (COLAÇA; CONTE; CINELLI, 2018). Leitura que se dá no cotidiano, em experiências concretas do dia a dia da vida dessas, com a luta pela alimentação saudável, pelo direito à terra, pela manutenção da biodiversidade das sementes, pelo cuidado com a 
O movimento de mulheres camponesas na construção do feminismo camponês popular | Débora $F$. dos Santos \& Silvia Aparecida Zimmermann

natureza e com as pessoas, pelo enfrentamento à violência doméstica, entre inúmeras outras realidades pertencentes no cotidiano e nas labutas das mulheres rurais latino-americanas, conforme relatam as entrevistadas. Seibert e Rodrigues (2017) fazem uma aproximação teórica entre o FCP e as teorias marxistas e apresentam relações muito próximas entre a identificação do ser camponesa, indígena e negra na América Latina, o território e o entender-se mulher.

$[\ldots]$ as mulheres que constroem o Feminismo Camponês e Popular têm em comum a relação com a terra, o território e a produção de alimentos, como identidade que as unifica, mas com a certeza de que essencialismos e romantismos em relação às identidades indígenas, camponesas e negras devem ser superadas, assim como devem ser eliminadas todas as formas de hierarquias ou relações de desigualdade reproduzidas no interior destas comunidades (SEIBERT; RODRIGUES, 2017, p. 12).

A construção do FCP teve início há muitas décadas pela realidade concreta de lutas e organização politica das mulheres rurais brasileiras e latino-americanas, sendo construída todo dia, no acúmulo de concepções políticas teóricas organizativas. Teoricamente, começa a ser discutido oficialmente em 21 e 22 de novembro de 2015 com o I Seminário Internacional com o tema: Feminismo Camponês e Popular, evento realizado em Luziânia, em Goiás, e organizado pelo MMC, com participação da CLOC, dos movimentos sociais vinculados à Via Campesina, do Levante Popular da Juventude, universidades e organizações urbanas de mulheres (MMC, 2019). Como ressaltado pelas entrevistadas, que estiveram presente nas edições ${ }^{17}$, o primeiro Encontro teve um caráter mais interno de decisão sobre as ações concretas, qual feminismo pensavam construir que abraçasse as bandeiras de lutas do movimento, quais seriam as diretrizes deste feminismo, entre outras decisões que cabiam às próprias mulheres do MMC. Para o evento foram convidadas as pesquisadoras que tratavam do tema na graduação, mestrado, doutorado ou na própria vivência, em três blocos temáticos: Violência, Direitos e Autonomia.

Já os II e III Seminário Internacional Feminismo Camponês e Popular (FIGURAS 4 e 5 consecutivamente) foram realizados em março de 2016 e

\footnotetext{
17 A Eloisa participou das duas primeiras edições, apresentando no primeiro seminário sua pesquisa de TCC de um estudo de caso do sudoeste do Paraná sobre a superação da violência através da autonomia econômica e a concretude da Lei Maria da Penha. A Bianca participou de todos os seminários e conta que foi quem construiu a metodologia adotada nas reuniões.
} 
O movimento de mulheres camponesas na construção do feminismo camponês popular | Débora $F$. dos Santos \& Silvia Aparecida Zimmermann

setembro de 2017, respectivamente. Estes ganharam amplitude internacional, com a participação de mulheres de movimentos sociais do Paraguai, Bolivia e Moçambique, que somaram-se a construção, discussão e encaminhamentos frente ao FCP (MMC, 2017).

\section{Figura 4 - II Seminário Internacional Feminismo Camponês e Popular, realizado em Luziânia, Goiás em 2016}

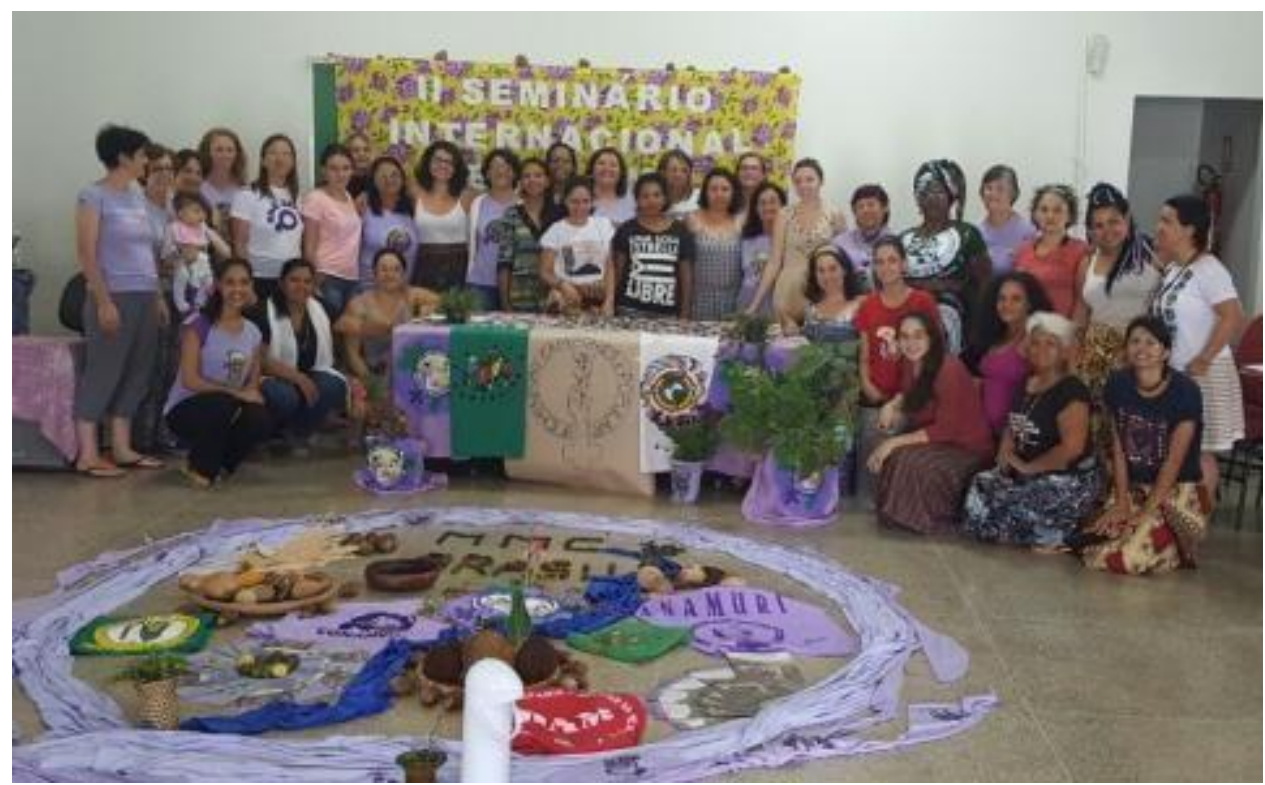

Fonte: Site oficial do MMC, 2016.

Figura 5 - III Seminário Internacional Feminismo Camponês e Popular, realizado em Luziânia, Goiás em 2017

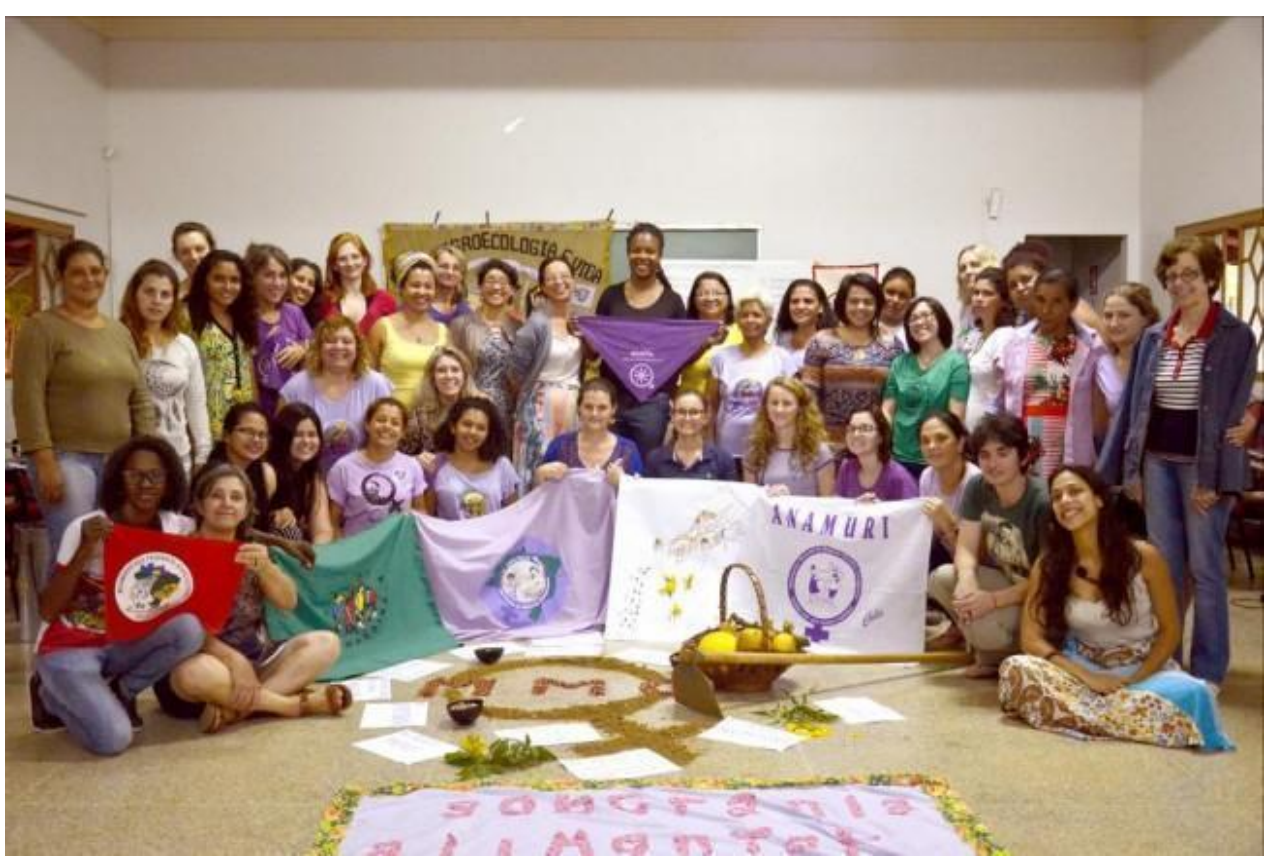

Fonte: Site oficial do MMC, 2017. 
O movimento de mulheres camponesas na construção do feminismo camponês popular | Débora $F$. dos Santos \& Silvia Aparecida Zimmermann

Como ressalta Táboas (2018) em seu livro É LUTA! Feminismo Camponês Popular e enfrentamento à violência, o FCP pode ser dividido em três elementos fundamentais. O primeiro, o compromisso com o projeto contra-hegemônico de produção agro e hidronegócio, e como resposta a proposição da agricultura baseada na agroecologia e na produção de alimentos saudáveis, com práticas de recuperação da biodiversidade de sementes crioulas, das plantas historicamente consumidas, das plantas medicinais, das plantas alimentícias não convencionais (PANCS), das flores, dos quintais produtivos, etc. O segundo elemento é o vínculo estreito com o território habitado, elemento que possui relação direta com o terceiro, que é a centralidade da razão produtiva nas experiências concretas das mulheres camponesas. Diante disso, perder o vínculo com o que às tornam camponesas, é relacionado ao que às fazem sentirem-se mulheres.

Outro ponto central do FCP é o enfrentamento à violência contra as mulheres rurais, que Táboas (2018) trata como uma práxis do FCP, composta por múltiplas questões e agravada pelo distanciamento de vizinhos e comunidades. Historicamente, no Brasil o domínio da terra sempre foi masculino e branco, em sua maioria, o que pode ser encarado como uma violência, posto que as mulheres rurais trabalham, produzem, cuidam, e não são reconhecidas como trabalhadoras rurais e parceiras dessa terra. Por isso, o FCP não se refere somente à violência física, verbal, psicológica, mas também patrimonial.

Outra análise do FCP, cabe ressaltar, é feita por Calaça, Conte e Cinelli18 (2018) através de um debate teórico evidenciados por nove pontos importantes e que expressam o entendimento das autoras militantes do MMC. O primeiro refere-se à centralidade do trabalho, da importância frente às unidades de produção, nas águas e nas florestas, percebendo a contribuição das camponesas não apenas na reprodução familiar e no cuidado, mas também responsáveis por boa parte do trabalho produtivo, oriundo das noções da agroecologia e a luta por soberania alimentar. O segundo relaciona-se ao se entender feminista e como esse é um processo coletivo e, concomitantemente, individual, que nesse tempo o MMC vem construindo um

18 Entre as autoras, duas possuem dissertações e teses sobre o MMC Cinelli (2012); Conte (2011); Cinelli (2016); Conte (2014). 
O movimento de mulheres camponesas na construção do feminismo camponês popular | Débora $F$. dos Santos \& Silvia Aparecida Zimmermann

feminismo a partir do dia a dia das camponesas. Muitas sem acesso à escolarização e localizadas em áreas caracterizadas pela precariedade de acesso aos bens de direitos. Contudo, isso não significa que todas as mulheres se identifiquem como feministas, mas certamente possuem práticas condizentes ao feminismo nas tarefas individuais e em conjunto com o MMC.

O terceiro ponto ressaltado pelas autoras é a característica unitária da luta feminista no FCP, a importância da participação de outras mulheres de movimentos mistos e organizados por outras mulheres, ressaltando a importância da luta pela libertação das mulheres ser maior que o próprio movimento e a importância da construção da unidade na diversidade de mulheres. Dialogando com o ponto anterior, o quarto refere-se à visibilidade da diversidade na unidade, referindo-se às características das mulheres identificadas com o FCP: negras e brancas, pobres e nem tão pobres assim, agricultoras, trabalhadoras rurais, sem-terra, indigenas, assentadas e reassentadas da reforma agrária, extrativistas, lésbicas, entre muitas outras. As autoras ressaltam que questões referentes ao corpo, aos direitos reprodutivos e o enfrentamento ao racismo o MMC já tratam há algum tempo, mas a questão de diversidade sexual é mais recente no movimento.

O quinto tópico trata da importância da auto-organização na construção de pautas específicas, de lutas coletivas, na compreensão da teoria e prática feminista, na superação de medo e inseguranças, no fortalecimento politico, nas possibilidades reais de liderança e no autocuidado e cuidado com as outras camponesas. O sexto ponto evidenciado pelas autoras, considerado por elas com poucos avançados em termos de políticas públicas para o campo, é o enfrentamento à violência contra as mulheres e como as mulheres que vivem em comunidades rurais, assentamentos e reassentamentos rurais, água e florestas são menos assistidas pelo Estado, agravado pela distância entre vizinhos e pela ausência de delegacias especializadas no atendimento às mulheres ${ }^{19}$.

O sétimo principio relaciona-se ao fato do FCP partir de um leito histórico de luta vivenciado pelas mulheres socialistas, comunistas, indígenas, negras e todas que resistiram frente às opressões de classe, raça e

\footnotetext{
19 Delegacia Especializada de Atendimento à Mulher (DEAM) são unidades da Polícia Civil especializada no atendimento às mulheres em situação de violência, criadas através a Portaria $\mathrm{N}^{\circ} 3.088$ de 23 de dezembro de 2011.
} 
O movimento de mulheres camponesas na construção do feminismo camponês popular | Débora $F$. dos Santos \& Silvia Aparecida Zimmermann

gênero. Algumas mulheres tidas como modelos são Rosa Luxemburgo, Clara Zetkin, Saffioti, Krupskaya, Zilda Xavier, Rose Marie Muraro, Ivone Gebara e Nancy Cardoso ${ }^{20}$, entre outras. O penúltimo ponto revela a necessidade da construção de uma outra sociedade sob outros valores, a desnaturalização de espaços e concepções historicamente reproduzidos, que enaltecem as divisões de classe, raça e gênero, e que fazem as militantes camponesas viverem uma contradição dialética no dia a dia. Quando rezam, mas lutam contra o sistema religioso buscando e redescobrindo outras lógicas espirituais, quando são pacatas, mas quebram regras que as oprimem, são tidas como sensíveis e frágeis, mas lutam contra o sistema e as diversas formas de violência sob suas vidas, seus corpos e o planeta, e por último são conhecidas como sem conhecimento, mas reproduzem saberes preservados de geração a geração e que são até hoje fundamentais para a soberania alimentar e a reprodução saudável da vida. E por último, mas não menos importante, a agroecologia como modo de vida e relação entre humanos e a natureza de forma menos agressiva e que sustenta o modo de vida camponês. Modo de vida esse constituído de experimentos e misturas complexas de plantas realizadas por mulheres em diferentes biomas, encontrando em cada lugar, com suas características divergentes, a forma mais adequada de preservação, recuperação e disseminação de espécies, como alternativa real ao modelo do agronegócio.

Tudo isso apresentado como o FCP é entendido pelo MMC como um processo de libertação, mas também como de transformação das estruturas, e isso não acontece apenas no âmbito individual. É também formador de consciência, que se movimenta em um tripé dialético de formação política, organização popular e na luta das mulheres camponesas por sua libertação. No campo, a conquista da liberdade é um trabalho que deve ser feito a partir da base, de formação política, de conscientização das mulheres, do seu papel, etc., mas também composto pelo debate ideológico, e isso só possivel pela organização, e essa possibilitaria maiores condições de enfrentamento do tripé

\footnotetext{
20 Rosa Luxemburgo (1871-1919) filósofa e economista marxista; Clara Zetkin (1857-1933) professora, jornalista e marxista alemã; Heleieth Saffioti (1934-2010) sociológica marxista, professora, militante feminista e escritora; Nadejda Krupskaya (1869-1939) revolucionária bolchevique e pedagoga russa; Zilda Xavier Pereira (1925-2015) comunista e ex-guerrilheira; Rose Marie Muraro (1930-2014) escritora, intelectual e militante feminista; Ivone Gebara (1944-) freira católica, filósofa e teóloga feminista; Nancy Cardoso (-) professora, biblista, teóloga feminista e pastora da Igreja Metodista do Brasil.
} 
O movimento de mulheres camponesas na construção do feminismo camponês popular | Débora $F$. dos Santos \& Silvia Aparecida Zimmermann

da dominação e opressão da classe trabalhadora do campo e da cidade: o capitalismo, o patriarcado e o racismo.

Para a Bianca, o FCP mistura-se à sua atuação política e história de vida, pois teve acesso às teorias feministas ainda na faculdade, mas deixa explícito que seu entendimento atual de feminismo foi construído pela sua trajetória no MMC, pela forma que esse entende o feminismo. O FCP é a construção da liberdade e autonomia das mulheres rurais por elas mesmas, para além de perceberem formas de opressão, pensar a construção de novas relações igualitárias entre os gêneros. Ainda, Bianca aponta questões importantes para o debate:

Como as mulheres se organizaram para lutar e afirmar que são trabalhadoras rurais e que possuem direitos previdenciários se elas não são feministas? O que é ser feminista? Se dizer feminista, é saber seu significado teórico e discutir pautas clássicas feministas? Talvez um monte de camponesas organizadas no MMC até hoje nem saibam o que significa feminismo e morram de medo desta palavra, mas suas ações concretas de luta por direitos, por soberania alimentar, pela autonomia, por não viver com violência, é necessariamente uma luta feminista. Esse é o processo que visibilizamos com o FCP, dizendo que não existe um modelo de feminismo, que este se resume em liberdade e igualdade para as mulheres, quebrar com o patriarcado e com as relações de poder (Bianca, 21 junho 2018).

Por isso, o FCP não é divergente de nenhum feminismo, pelo contrário, ele se soma, com um recorte muito próprio e olha as particularidades visando o todo. Isso é importante para a luta de todas, trabalhadoras do campo e da cidade.

A Eloisa lembra que

O FCP possui como questão principal o protagonismo das mulheres na produção de alimentos saudáveis, mas é contra a visão essencialista da naturalização do cuidado à figura feminina, responsabilizando-as do cuidado de toda reprodução familiar. Essa naturalização é resultado da divisão sexual do trabalho que tornou as mulheres cativas no espaço doméstico, mas isso não é natural, nem essência, mas uma construção sociocultural do patriarcado, que justifica a dupla, tripla jornada de trabalho, o desgaste físico, psicológico e emocional das mulheres, as doenças decorrentes desse desgaste como a depressão, a violência contra às mulheres, etc.. (Eloisa, 22 de maio 2018).

A Eloisa afirma que o cuidado e as atividades domésticas nunca foram valorizados e valorados, feito somente quando tal trabalho é pago, o mesmo que é historicamente realizado pelas mulheres, como fazer comida (pães, bolos, bolachas, compotas, queijos, leite, banha, etc.), limpar a casa, cuidar 
O movimento de mulheres camponesas na construção do feminismo camponês popular | Débora $F$. dos Santos \& Silvia Aparecida Zimmermann

do quintal (com horta, flores, plantas medicinais, pequenos animais, etc.), cuidar dos enfermos e idosos, cuidar das crianças, cultivar sementes, "ajudar" na roça, entre inúmeros outros trabalhos que sem as mulheres a família rural não possuiria condições estruturais e econômicas para ficar no campo. Devese reconhecer e valorar esses trabalhos, e o reconhecimento devem ser expresso, principalmente, em políticas públicas.

\section{Considerações Finais}

A trajetória da organização das mulheres rurais aponta para a construção de um feminismo de traço rural e popular. As experiências de lutas e organizações de mulheres rurais começam a ser construídas a partir do momento em que as próprias mulheres rurais libertaram-se dos movimentos mistos, muitos deles mais vinculados às problemáticas urbanas.

De modo geral, o primeiro passo de liberdade para as mulheres é o sair de casa em busca dos direitos à elas negligenciados, ação que tarda, se comparado ao histórico da luta feminista mundial, mas que atualmente tornase referência na luta pela cidadania plena, reconhecimento profissional e fim da desigualdade. E que esta luta não poderia acontecer de outra maneira.

Quando as entrevistadas foram questionadas sobre se houve diálogo entre as lutas feministas de mulheres urbanas e a realidade das mulheres rurais, parece não ter acontecido, mas não porque as mulheres urbanas não quiseram dialogar com as rurais, ou outro motivo de desentendimento entre movimentos ou as próprias mulheres. Os principais causadores da desarticulação de movimentos de mulheres rurais e urbanas estariam no tripé da desigualdade: o capitalismo, o patriarcado e o racismo (TÁBOAS, 2018). Estes três fatores também são os responsáveis pela existência desses movimentos, que buscam modificar a realidade social das mulheres e uma articulação forte entre mulheres que lutam por melhores condições de vida.

Outro ponto a destacar na luta histórica dos movimentos autônomos de mulheres rurais é o protagonismo feminino, em que as experiências aconteceram e são organizadas, coordenadas, lideradas e praticadas por mulheres rurais, o que demandou algum tempo, para libertação e organização dessas mulheres. As vozes feministas foram historicamente silenciadas pela cultura patriarcal, racista e capitalista, mas quando existe a possibilidade de 
O movimento de mulheres camponesas na construção do feminismo camponês popular | Débora $F$. dos Santos \& Silvia Aparecida Zimmermann

serem ouvidas, as mulheres rurais e urbanas devem falar. Para que as mulheres sufragistas, urbanizadas, estudadas e de classe alta no século XIX tivessem suas vozes ouvidas em seu tempo, milhares de outras foram caladas. E para que a mulher rural latino-americana marginalizada possua lugar de fala, muitas mulheres historicamente gritaram para que isso fosse possivel.

\section{Referências:}

ADÃO, Nilton M. Lacerda. Movimento de mulheres camponesas: a origem religiosa e o cuidado na estrutura familiar. Clélia Peretti (org.). Congresso de Teologia da PUCPR. Curitiba. Anais eletrônicos. 2011. p. 174-186.

BETTO, Janaina; PICCIN, Marcos Botton. Movimento de Mulheres Camponesas (MMC) e o percurso de sua luta feminista. 2017. Disponivel: https://journals.openedition.org/amerika/8202. Último acesso em: 26/05/2019.

BRASIL. Emenda Constitucional no 20. Brasília, DF. 15 de dezembro de 1998.

BRASIL. Emenda Constitucional n41. Brasília, DF. 19 de dezembro de 2003.

CALAÇA, M.; CONTE, I.; CINELLI, C. Feminismo camponês e popular: uma história de construções coletivas. Revista Brasileira de Educação do Campo, v. 3, n. 4, p. 1156-1183, 23 dez. 2018.

CAMPANHA DA VIA CAMPESINA INTERNACIONAL: sementes patrimônio do povo a serviço da humanidade. Temporalis, Distrito Federal, Brasil, ano 12, n. 24, p. 471-4772, jul./dez. 2012.

CINELLI, C. O educativo na experiência do MMC: resistência, enfrentamento e libertação. (Tese de doutorado). Universidade Federal do Rio Grande do Sul, Porto Alegre. 2016.

CINELLI, C. Programa de Sementes Crioulas de Hortaliças: experiências e identidades no MMC. (Dissertação de mestrado). Universidade Regional do Noroeste do Rio Grande do Sul, Ijuí. 2012.

CLOC, Coordenadora Latino Americana de Organizações do Campo. Quem somos. Site oficial, junho de 2010.

CONTE, I. Mulheres Camponesas em luta: resistência, libertação e empoderamento. (Dissertação de mestrado). Universidade Regional do Noroeste do Rio Grande do Sul, Unijuí. 2011.

CONTE, I. O processo educativo da luta e o trabalho das mulheres: Via Campesina o Brasil, UNORCA/UNMIC e CONAMI no México. (Tese de doutorado). Universidade Federal do Rio Grande do Sul, Porto Alegre. 2014. 
O movimento de mulheres camponesas na construção do feminismo camponês popular | Débora $F$. dos Santos \& Silvia Aparecida Zimmermann

FREITAS, Isabel; MORI, Natália; FERREIRA, Verônica (org). A seguridade social é um direito das mulheres. Vamos a luta! Centro Feminista de Estudos e Assessoria (CFEMEA). Brasília, 2010.

GADELHA, Renata R; RODRIGUES, Sandra M. R; MARQUES, Siomara A; ANDRIOLI, Antônio I. História das origens do Movimento de Mulheres Camponesas do Paraná (1981-2016). Revista Ártemis, Vol. XXIII nº 1; janjun, 2017. 180-195 pp.

GASPARETO, Sirlei A. K. A construção de saberes no Movimento de Mulheres Camponesas: uma análise a partir do programa de sementes crioulas no oeste de Santa Catarina - Brasil. Tese (Doutorado em Desenvolvimento Regional) - Universidade de Santa Cruz do Sul UNISC, 2017.

INSTITUTO BRASILEIRO DE GEOGRAFIA E ESTATÍSTICA IBGE. Descrição do semiárido. Site oficial, 20_. Disponivel em: https://www.ibge.gov.br/geociencias-novoportal/cartas-e-mapas/mapasregionais $/ 15974$-semiarido-brasileiro. $h \mathrm{tml} ?=\& \mathrm{t}=\mathrm{o}-\mathrm{que}-\mathrm{e} . \quad$ Último acesso: 20/05/2019.

MANO, Maíra Kubík. Discurso das mulheres e confronto midiático: uma análise sobre a ação da Via Campesina na Aracruz Celulose. Anais do IV Simpósio Lutas Sociais na América Latina, GT 7 Feminismo e Marxismo na América Latina. Universidade Estadual de Londrina UEL. Londrina, PR. 14 a 17 set. 2010.

MARTINS, Fabio; BRUNETTO, Sarue. Movimento das Mulheres Camponesas e sua relação de resistência com a ditadura militar. Revista Santa Catarina em História - Florianópolis - UFSC - Brasil ISSN 1984-3968, v.8, n.1, 2014.

MENDES, Ivete M. A; MUNARINI, Carmen. Recuperação, produção e melhoramento de sementes de hortaliças em Santa Catarina. In Biodiversidade e agricultores fortalecendo o manejo comunitário. 2007. Disponivel:

https://www.researchgate.net/publication/253328170_Biodiversidade_e_ag ricultores_Fortalecendo_manejo_comunitario. Último acesso: 20/05/2019.

MOVIMENTO DE MULHERES CAMPESINAS. Lutas, Missão e Objetivos. Site oficial, 2016/2017. Disponivel: http://www.mmcbrasil.com.br/site/. Último acesso em 09/08/2019.

MOVIMENTOS DA MULHER TRABALHADORA RURAL (MMTR-NE). Quem somos. Site oficial, 2018. Disponivel em: http://www.mmtrne.org.br/. Último acesso em: 20/06/2019.

SEIBERT, Iridiani Graciele. RODRIGUES, Sandra Marli da Rocha. Aproximação teórica entre o Feminismo Camponês e Popular e o Marxismo Latino-Americano. Anais VIII Simpósio Internacional de Geografia Agrária | IX Simpósio Nacional de Geografia Agrária. Curitiba, Paraná. Novembro, 2017. 
O movimento de mulheres camponesas na construção do feminismo camponês popular | Débora $F$. dos Santos \& Silvia Aparecida Zimmermann

TÁBOAS, Ísis Menezes. É LUTA! Feminismo Camponês Popular e enfrentamento à violência. Editora Lumen Juris, Brasília. 2018. 